\title{
Post-transcriptional modifications in the small subunit ribosomal RNA from Thermotoga maritima, including presence of a novel modified cytidine
}

\author{
REBECCA GUYMON, ${ }^{1,3}$ STEVEN C. POMERANTZ, ${ }^{1,4}$ J. NICHOLAS ISON, ${ }^{1}$ PAMELA F. CRAIN, ${ }^{1}$ \\ and JAMES A. MCCLOSKEY ${ }^{1,2}$ \\ ${ }^{1}$ Department of Medicinal Chemistry, University of Utah, Salt Lake City, Utah 84112, USA \\ ${ }^{2}$ Department of Biochemistry, University of Utah, Salt Lake City, Utah 84112, USA
}

\begin{abstract}
Post-transcriptional modifications of RNA are nearly ubiquitous in the principal RNAs involved in translation. However, in the case of rRNA the functional roles of modification are far less established than for tRNA, and are subject to less knowledge in terms of specific nucleoside identities and their sequence locations. Post-transcriptional modifications have been studied in the SSU rRNA from Thermotoga maritima (optimal growth $80^{\circ} \mathrm{C}$ ), one of the most deeply branched organisms in the Eubacterial phylogenetic tree. A total of 10 different modified nucleosides were found, the greatest number reported for bacterial SSU rRNA, occupying a net of $\sim 14$ sequence sites, compared with a similar number of sites recently reported for Thermus thermophilus and 11 for Escherichia coli. The relatively large number of modifications in Thermotoga offers modest support for the notion that thermophile rRNAs are more extensively modified than those from mesophiles. Seven of the Thermotoga modified sites are identical (location and identity) to those in $E$. coli. An unusual derivative of cytidine was found, designated $N-330\left(M_{r} 330.117\right)$, and was sequenced to position 1404 in the decoding region of the rRNA. It was unexpectedly found to be identical to an earlier reported nucleoside of unknown structure at the same location in the SSU RNA of the archaeal mesophile Haloferax volcanii.
\end{abstract}

Keywords: post-transcriptional modification; Thermotoga maritima; Haloferax volcanii; small ribosomal subunit RNA; liquid chromatography-mass spectrometry; electrospray ionization

\section{INTRODUCTION}

Relatively little is known concerning the specific roles of post-transcriptional modifications in rRNA (summarized

${ }^{3}$ Present addresses: ARUP Laboratories, 500 Chipeta Way, Salt Lake City, UT 84108, USA. ${ }^{4}$ Centocor, 145 King of Prussia Rd., Radnor, PA 19087, USA.

Reprint requests to: James A. McCloskey, University of Utah, $30 \mathrm{~S}$. 2000 East, Rm. 311A, Salt Lake City, UT 84112-5820, USA; e-mail: mccloskey@biochem.utah.edu; fax: (801) 581-7087.

Abbreviations: LC/ESI-MS, combined liquid chromatography-electrospray ionization mass spectrometry; $\Psi$, pseudouridine; $\mathrm{m}^{3} \mathrm{U}, 3$-methyluridine; $\mathrm{Cm}, 2^{\prime}$-O-methylcytidine; $\mathrm{m}^{4} \mathrm{Cm}, \mathrm{N}^{4}, \mathrm{O}-2^{\prime}$-dimethylcytidine; $\mathrm{m}^{5} \mathrm{C}$, 5-methylcytidine; $\mathrm{m}^{2} \mathrm{G}, \mathrm{N}^{2}$-methylguanosine; $\mathrm{m}^{7} \mathrm{G}, 7$-methylguanosine; Am, 2'-O-methyladenosine; $\mathrm{m}_{6}^{2} \mathrm{~A}, N^{6}, N^{6}$-dimethyladenosine; MS/MS, tandem mass spectrometry; $\mathrm{M}^{3-}$, molecular ion having three negative charges, corresponding to loss of three protons from the neutral molecule $\mathrm{M}$, i.e., $(\mathrm{M}-3 \mathrm{H})^{3-}$ (analogous definitions for other charge states); $\mathrm{MH}^{+}$, protonated molecule ion; $\mathrm{BH}_{2}^{+}$, protonated base ion in which $\mathrm{B}$ is the base fragment attached to ribose and $\mathrm{BH}$ corresponds to the neutral base; CID, collision-induced dissociation.

Article published online ahead of print. Article and publication date are at http://www.rnajournal.org/cgi/doi/10.1261/rna.361607. by Decatur and Fournier 2002), in contrast to tRNA, in which a number of modification functions are slowly being unraveled (Agris 2004). In the case of rRNA, the influence of nucleotide modification on ribosome assembly and maturation (Bachellerie and Cavaillé 1998; Maden 1998; Mason 1998) is perhaps the best documented (Vaughan et al. 1967; Cunningham et al. 1990, 1991; Rydén-Aulin et al. 1993; Sirum-Connolly and Mason 1993; Sirum-Connolly et al. 1995; Green and Noller 1996), but mechanistic details at the molecular level have been scant. There is strong circumstantial evidence in the archaeal thermophiles that ribose methylation at $\mathrm{O} 2^{\prime}$ provides a significant mechanism for thermal stabilization of rRNA (Noon et al. 1998) and of archaeal tRNA (Kowalak et al. 1994; Noon et al. 2003), primarily through reduced flexibility resulting from strong thermodynamic enforcement of the C3'-endo sugar conformation (Kawai et al. 1992). Also, from the standpoint of function, selective methylation of rRNA nucleotides provides, in some instances, an effective mechanism for 
conferring resistance to antibiotics that target the bacterial ribosome (Douthwaite et al. 2005).

Many of the structures and sequence locations of rRNA modifications are relatively well conserved (Maden 1990; Rozenski and McCloskey 2005) and exhibit distinct differences among the three principal evolutionary domains, Archaea, Bacteria, and Eukarya. The complete modification map for SSU rRNA of the bacterial thermophile Thermus thermophilus was recently completed (Guymon et al. 2006) and found to exhibit a notably lower level of modification than that of the archaeal thermophile Sulfolobus solfataricus (Noon et al. 1998) growing in the same temperature range $\left(70^{\circ} \mathrm{C}-75^{\circ} \mathrm{C}\right)$, and a pattern of modification (nucleoside structures and sequence locations) unexpectedly similar to that in the mesophile Escherichia coli. For a tabulation of E. coli rRNA modifications and leading references see http://medlib.med.utah.edu/RNAmods/.

We have examined the SSU rRNA modifications in a second bacterial thermophile, Thermotoga maritima (optimal growth at $80^{\circ} \mathrm{C}$ ) (Huber et al. 1986), an organism placed by small subunit ribosomal RNA (SSU rRNA) phylogeny as one of the most deeply rooted organisms in the Eubacterial tree. Analysis of the complete Thermotoga genome sequence (Nelson et al. 1999) as well as earlier data (Aravind et al. 1998) led to conclusions that extensive lateral gene transfer between T. maritima and Archaea have occurred, reflected in the unusually high percentage $(24 \%)$ of genes in T. maritima that are similar to those in Archaea. Examination of T. maritima SSU rRNA in the present study was intended in part to establish whether its modifications are to any extent archaeal in nature, and thus reflecting possible horizontal transfer of RNA modification enzymes. Further, this study serves to extend the knowledge base of bacterial SSU rRNA modification patterns (Rozenski and McCloskey 2005; Guymon et al. 2006) beyond E. coli and T. thermophilus, the only bacteria for which complete SSU modification maps are available, and beyond organisms for which RNase T1 catalog data were reported (Rozenski and McCloskey 2005) in which modifications were sometimes reported to occur, often without chemical identity of the modified nucleoside or firm knowledge of its sequence location in the 16S RNA molecule.

\section{RESULTS}

\section{Modified nucleoside content of $T$. maritima 16S rRNA}

Identities and approximate numbers of modified nucleosides, determined by LC/ESI-MS analysis of total nucleoside digests of 16S rRNA (Supplemental Fig. S1, at http:// library.med.utah.edu/mccloskey) are: $\Psi$ (3.8 residues), $\mathrm{m}^{3} \mathrm{U}(1.0), \mathrm{m}^{4} \mathrm{Cm}(1.2), \mathrm{m}^{5} \mathrm{C}$ (0.73), $\mathrm{Cm}$ (0.82), unknown nucleoside N-330 (UV molar absorptivity not known, so stoichiometry not estimated), $\mathrm{m}^{2} \mathrm{G}(2.3), \mathrm{m}^{7} \mathrm{G}$ (1.1), Am (trace level to 1.3; see text), and $\mathrm{m}_{6}^{2} \mathrm{~A}(2.1)$.

\section{Identification and sequence location of modified residues in $T$. maritima $16 S$ rRNA}

RNA modifications represented by changes in mass from the parent nucleotide were mapped. The locations of pseudouridines, which are mass silent, were not measured beyond the estimation of 3.8 net residues in the molecule. Chromatographic separation of RNase T1 digestion products of T. maritima SSU rRNA is shown in Figure 1, with the corresponding mass data for modified oligonucleotides given in Table 1. A section of the RNase U2 chromatogram in which modified oligonucleotides were eluted is shown in Supplemental Figure S2.

To a certain extent the procedures used for identification and sequence placement of modified residues are analogous to those recently used and described in a study of T. thermophilus SSU rRNA (Guymon et al. 2006). Therefore, descriptions of results for seven modified residues in the present work can be found in the Supplemental Data section. These are: $m^{7} \mathrm{G}-527$ (Supplemental Fig. S3), $\mathrm{m}^{2} \mathrm{G}-966$ and $\mathrm{m}^{5} \mathrm{C}-967$ (Supplemental Fig. S4), $\mathrm{m}^{2} \mathrm{G}-1051$ (Supplemental Table S2), m ${ }^{4} \mathrm{Cm}-1402$ (Supplemental Fig. S5), Cm-1409 (Supplemental Figs. S6,S7), and 1518- $\mathrm{m}_{6}^{2} \mathrm{Am}_{6}^{2} \mathrm{~A}-1519$ placement. Results for $\mathrm{N}-330-1404, \mathrm{~m}^{3} \mathrm{U}-1498$, and Am1499 follow below.

\section{N-330-1404}

The presence of a novel structurally unknown nucleoside of $M_{\mathrm{r}} 330$ at position 1404 is indicated from the following four lines of evidence. (1) The sequencing spectrum of T1 oligonucleotide $M_{\mathrm{r}} 1393$ (Supplemental Fig. S5) can be assigned only if a unique nucleotide residue mass of 392 $\left(\mathrm{N}-330 \mathrm{p}\right.$ minus $\left.\mathrm{H}_{2} \mathrm{O}\right)$ is used in the third nucleotide position. (2) The base ${ }^{-}\left(\mathrm{m} / z\right.$ 197) and $\mathrm{N}>\mathrm{p}^{-}(\mathrm{m} / z$ 391) monomer fragment ion signals (Supplemental Table S1) were assigned from the data in Supplemental Figure S5 and time aligned as shown in Supplemental Figure S8. Ions

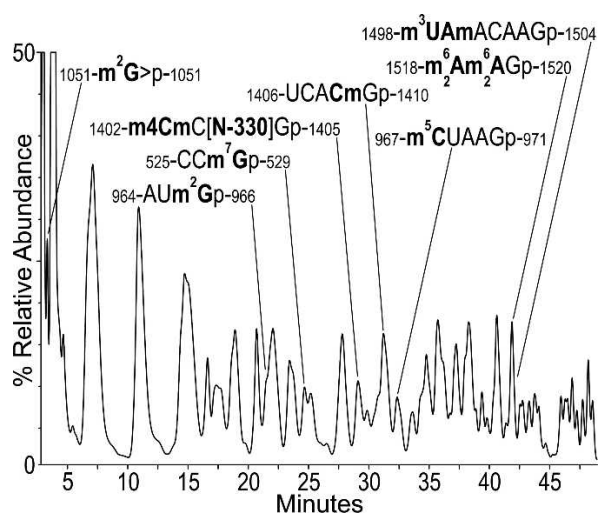

FIGURE 1. HPLC separation of RNase T1 digestion products of T. maritima $16 \mathrm{~S}$ rRNA, annotated to show modified oligonucleotides determined from mass shifts in conjunction with data in Table 1. UV absorbance detection at $260 \mathrm{~nm}$. 


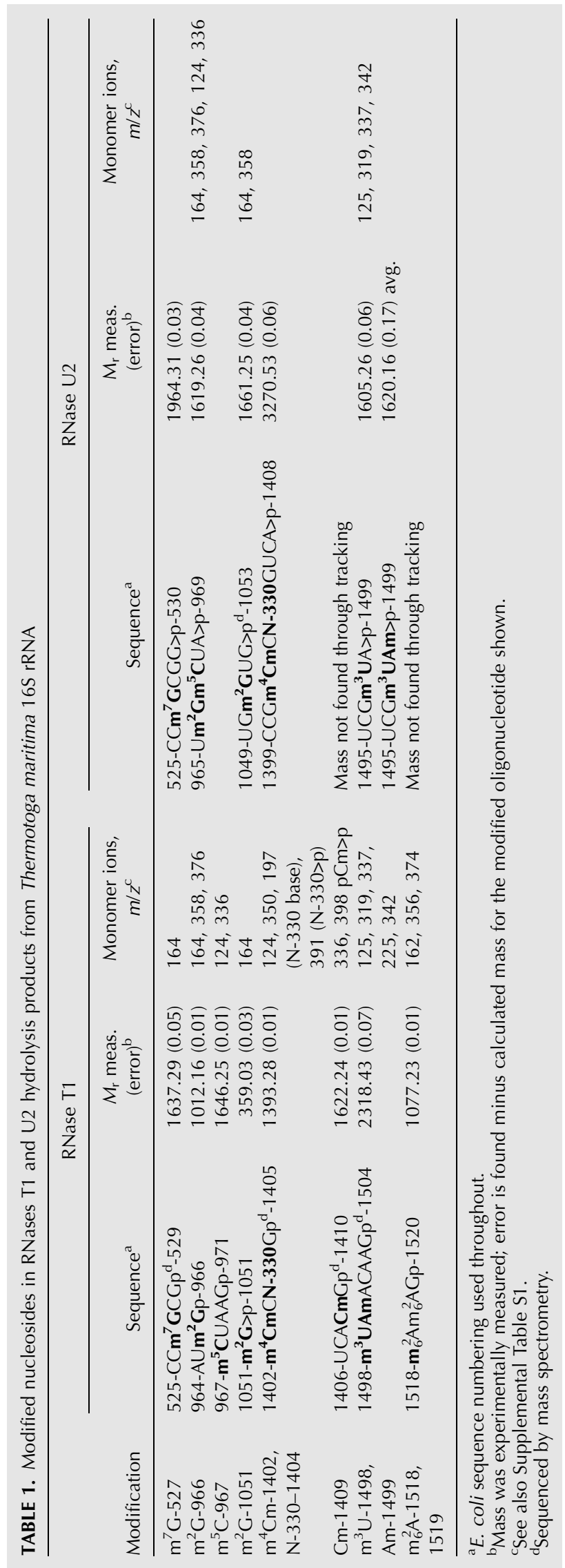


corresponding to the modified residue $\mathrm{m}^{4} \mathrm{Cm}$, whose presence is indicated from the total nucleoside analysis data in Supplemental Figure S1, were also time aligned. The exact coelution pattern of ions from $\mathrm{N}-330$ and $\mathrm{m}^{4} \mathrm{Cm}$ is shown in Supplemental Figure S8, and supports the presence of both of those nucleosides in the T1 oligonucleotide $M_{\mathrm{r}}$ 1393. The characteristic bacterial nucleoside $\mathrm{m}^{4} \mathrm{Cm}$ serves as an internal marker for position 1402 (Rozenski and McCloskey 2005) and correlates with the full oligonucleotide sequence derived by mass spectrometry in Supplemental Figure S5. (3) The presence of a basemodified unknown nucleoside of $M_{\mathrm{r}} 330\left(\mathrm{MH}^{+}, \mathrm{m} / z\right.$ 331; $\mathrm{BH}_{2}^{+}, m / z 199 ; \lambda_{\max } 270$ ) eluting at $3.85 \mathrm{~min}$ in the total nucleoside digest of Thermotoga 16S rRNA, Supplemental Figure S1. (4) Modification of the universal C-1404 was also reported in several other bacterial SSU rRNAs (although not in E. coli) (Rozenski and McCloskey 2005), but not the identity of the modification.

$m^{3} U-1498$ and Am-1499

Assignment of the unusual tandem methylation sites 1498 and 1499 was made primarily through the T1 product $M_{\mathrm{r}}$ 2318 (Table 1). The experimental mass 2318.43, using the corresponding gene sequence to calculate allowable RNA sequences, solely designates the unique sequence segment as shown in Table 1 corresponding to nucleotides 14981504 with two methyl groups. The sequence mass spectrum of this T1 fragment (Fig. 2) requires, through the presence of a clear $y_{1}-y_{5}$ ion series (McLuckey et al. 1992), that the methyl groups be confined to the first two nucleotides. The abundant methyluracil base ion $m / z 125$, in conjunction with the total nucleoside census (Supplemental Fig. S1) then implies $\mathrm{m}^{3} \mathrm{U}$ in position 1498 and Am, the only methylated $\mathrm{A}$ in the rRNA, at position 1499. (No methyladenine base

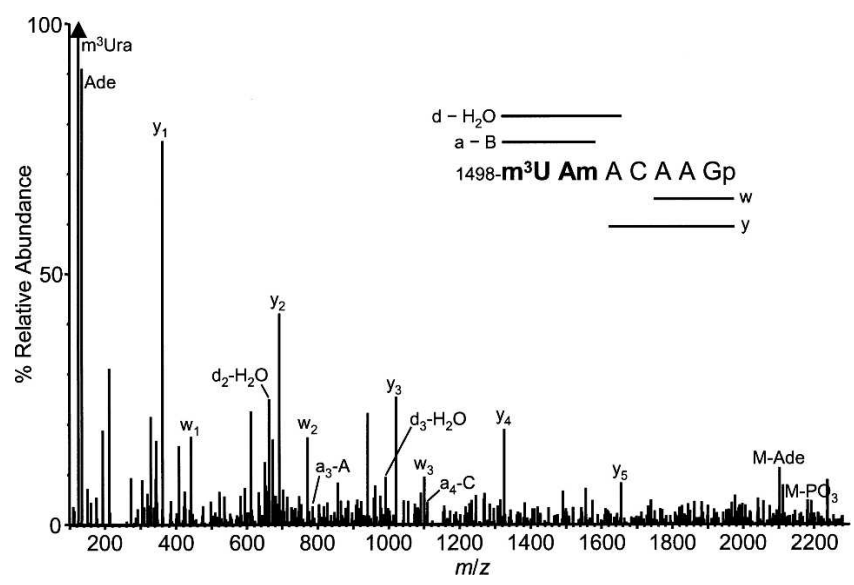

FIGURE 2. Product ion mass spectrum from RNase T1 fragment $M_{\mathrm{r}}$ 2318 , showing $\mathrm{m}^{3} \mathrm{U}-1498$ adjacent to Am-1499. For clarity, only peaks used for sequence assignment are annotated. Sequence coverage from the four sequence ion series $\left(\mathrm{a}-\mathrm{B}, \mathrm{d}-\mathrm{H}_{2} \mathrm{O}, \mathrm{w}\right.$, and $\mathrm{y}$ ) (McLuckey et al. 1992) is shown by horizontal bars. ion, $m / z$ 148, was observed). This methylation pattern was supported by the finding in the U2 digest of the 3 -truncated version of this sequence but having an extension of three nucleotides on the $5^{\prime}$ end, $M_{\mathrm{r}} 1620$ (see Table 1). However, the assignment of Am-1499 in these RNase products appeared to be at odds with the absence of the methylribose cyclic phosphate ion $(\mathrm{m} / z 225)$ in the spectrum, usually a strong indicator of presence of a ribose-methylated nucleotide (Phillips and McCloskey 1993). To address this point the product ion mass spectrum of chemically synthesized $\mathrm{m}^{3} \mathrm{UAmACAAGp}$ was acquired. It appeared essentially identical (data not shown) to the mass spectrum displayed in Figure 2, including the absence of ion $m / z 225$. The sequence of the Am-containing region is therefore assigned as shown in Table 1. The occurrence of Am is further supported by its presence in the total nucleoside digest (Fig. S1), with $\mathrm{MH}^{+}$and $\mathrm{BH}_{2}^{+}$ions appearing at the expected retention time (Pomerantz and McCloskey 1990). Interestingly, a second culture of T. maritima showed an otherwise very similar overall modification data set, but with the 1495-1499 fragment occurring primarily as $M_{\mathrm{r}} 1605.2$ (see Table 1), i.e., with one fewer methyl group. We interpret this finding, taken in conjunction with variable amounts of Am found in nucleoside total digests from two different $T$. maritima cultures, as an indication that the level of Am-1499 is both substoichiometric and variable in the rRNA. To our knowledge, this is the first report of Am in RNA from bacteria; however, using LC/ESI-MS we have observed Am in unfractionated tRNA from E. coli MRE 600 (F. Qiu and J. McCloskey, unpubl., 1998).

\section{3'-Terminal RNase T1 fragment from $T$. maritima $16 S$ rRNA}

The terminal fragment is a 15-mer, expected to contain the anti-Shine-Dalgarno mRNA-binding sequence. Because of the recent unusual finding of adjacent pseudouridines at 1540 and 1541 in the $3^{\prime}$-tail of T. thermophilus (Guymon et al. 2006), the Thermotoga 3'-terminal fragment was subjected to a $\Psi$ detection protocol (Pomerantz and McCloskey 2005) using LC/ESI-MS/MS. No $\Psi$ was detected. The terminal fragment was mass measured as 4591.7 (4591.60 calc.), and MS-sequenced as AUCACCUCCUUUCUAOH (Supplemental Fig. S9), thus revealing the molecular terminus as $\mathrm{AOH}-1545$ (E. coli numbering) in the processed 16S molecule.

\section{Presence of nucleoside N-330 in Haloferax volcanii $16 S$ rRNA}

The discovery of a new modified nucleoside in the Thermotoga SSU at the same position previously described as containing a modified cytidine in $H$. volcanii $16 \mathrm{~S}$ rRNA (Gupta et al. 1983) prompted a revisit of our previously 
published study of the Haloferax SSU RNA modifications (Kowalak et al. 2000). When the ion chromatograms for the diagnostic $\mathrm{MH}^{+}$and $\mathrm{BH}_{2}^{+}$ions for N-330 nucleoside $(\mathrm{m} / \mathrm{z} 331$ and 199, respectively) were extracted from our Haloferax total nucleoside digest data, their presence was confirmed by the appearance of these two ions in a peak exactly coeluting at $3.6 \mathrm{~min}$ (Fig. 3 ). If $\mathrm{N}-330$ is, in fact, the " $C$ ") nucleotide previously reported, the calculated mass of the predicted Haloferax N-330-containing T1 oligonucleotide $\left(\mathrm{CCC}^{\star} \mathrm{Gp}\right)$ would be $M_{\mathrm{r}}$ 1365.7. Reconstructed ion chromatograms were therefore generated using the $\mathrm{M}^{-}$ and $\mathrm{M}^{2-}$ ions $(\mathrm{m} / \mathrm{z} 1364.7$ and $\mathrm{m} / \mathrm{z} 681.8$, respectively), and for the $\mathrm{B}^{-}$ion for the base of N-330 $(\mathrm{m} / z$ 197). As shown in Supplemental Figure S10, each of the three ions forms a peak eluting at $16.0 \mathrm{~min}$, indicating $\mathrm{N}-330$ to be the modified $\mathrm{C}^{\star}$ nucleotide found by Woese and colleagues (Gupta et al. 1983).

\section{DISCUSSION}

\section{Modification identities and levels in T. maritima SSU RNA}

The finding of 10 different modified nucleosides at a net occupancy level of $\sim 14$ sequence sites marks $T$. maritima, and similarly T. thermophilus (Guymon et al. 2006), as the most extensively modified bacterial SSU RNAs presently known. Examination of a number of catalogued RNase T1 modification maps, although by their nature less complete than the full modification maps from E. coli (leading citations in ref. Bakin et al. 1994; see also http://medlib. med.utah.edu/RNAmods), and T. thermophilus (Guymon et al. 2006) SSU RNAs, suggests that the levels and identities of modifications are perhaps narrower and more

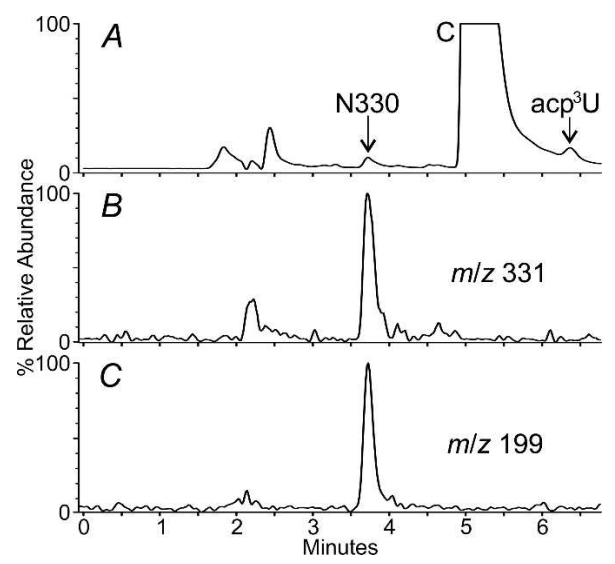

FIGURE 3. Demonstration of presence of modified nucleoside N-330 in a total nucleoside digest of $H$. volcanii $16 \mathrm{~S}$ rRNA (from previously acquired data) (Kowalak et al. 2000), detected from reconstructed ion chromatograms (RIC) for characteristic positively charged ions. (A) UV absorbance at $260 \mathrm{~nm}$. (B) RIC for the $\mathrm{MH}^{+}$ion of N-330 (m/z 331). (C) RIC for the protonated base fragment ion of N-330 $(\mathrm{m} / \mathrm{z} 199)$. conserved in Bacteria than in the Archaea and Eukarya. For example, modification levels in Archaeal 16S RNA range from five residues in $H$. volcanii (Gupta et al. 1983) to $\sim 38$ in S. solfataricus (Noon et al. 1998). Modification at $\sim 8-11$ SSU RNA sequence sites appears to be most common in bacteria ( $E$. coli has 11 ) while the elevation by about $30 \%$ of modification levels in the bacterial thermophiles (versus mesophiles) supports the conclusion that post-transcriptional modification in general serves to support structural stabilization of RNA (Sampson and Uhlenbeck 1988; Derrick and Horowitz 1993; Kowalak et al. 1994). The presence of 11 modifications was recently reported for T. thermophilus 23S rRNA (Mengel-Jorgensen et al. 2006), compared with $\sim 23$ in E. coli LSU RNA. This relative concentration is significantly lower than expected, based on our finding of 14 sites in the Thermus 16S RNA. However, the methodology used (Mengel-Jorgensen et al. 2006) was not designed to provide a complete census of modifications that required placement. As in the case of T. thermophilus (Guymon et al. 2006), rRNA modification levels in Thermotoga are characteristically much lower than in the Archaeal thermophiles growing at about the same temperature (Noon et al. 1998), with considerably less reliance on ribose O-2' methylation as a major means of structural stabilization. The finding of a net 3.8 residues of $\Psi$ in Thermotoga SSU RNA is notable in that $\Psi$ has been shown to play a strong, although often overlooked role in RNA stabilization (Davis 1995, 1998), and the level in Thermotoga appears to be the highest concentration of $\Psi$ reported in bacterial SSU RNAs (Ofengand and Rudd 2000).

The availability of three bacterial SSU RNA modification maps, E. coli (Brosius et al. 1978), Thermus (Guymon et al. 2006), and now Thermotoga, when coupled with information from T1 catalogs (Rozenski and McCloskey 2005) permits an estimation of the most highly conserved modification sites that are unique to bacteria, even though most of the T1 catalog data identify sites but not chemical structures of modifications. In bacteria these sites are $C^{\star}-967$ in $\mathrm{h} 31$ and $\mathrm{U}^{\star}-1498$ in the center of the decoding region in h44. An exception to the bacterial uniqueness of a modified C-967 appears to occur in the archaeon Thermoproteus tenax (Woese et al. 1984). The position 967 modification is reported to be $\mathrm{m}^{5} \mathrm{C}$ in all four cases in which the nucleoside structure has been established (E. coli, Thermus, Thermotoga, and Proteus). The adjacent modification $\mathrm{m}^{2} \mathrm{G}-966$, implicated in P-site tRNA binding (von Ahsen and Noller 1995; Korostelev et al. 2006), represents an essentially universal SSU modification site in all phylogenetic domains (Rozenski and McCloskey 2005) and is represented by an interesting diversity of modified nucleoside structures in Archaea and Eukarya (Kowalak et al. 2000). The identity of $U^{\star}-1498$ has been established specifically as $\mathrm{m}^{3} \mathrm{U}$ in the same four organisms. The unusual dimethylcytidine $\mathrm{m}^{4} \mathrm{Cm}-1402$ is unique to bacterial rRNA (Limbach et al. 1994), but this site appears to be 
modified in fewer than half of the reported cases (Rozenski and McCloskey 2005). In T. thermophilus the $\mathrm{m}^{4} \mathrm{Cm}$ residue serves to stabilize the third tRNA nucleotide by $\mathrm{H}$ binding of its phosphate to the 4-methylamino moiety (Korostelev et al. 2006).

\section{Modifications at the functional center of the ribosome}

As deduced in earlier literature, modification sites in bacterial SSU RNAs tend to occur, in three-dimensional space, near the decoding center of the RNA (Brimacombe et al. 1993; Decatur and Fournier 2002). Four of the 16S modifications $\left(\mathrm{m}^{2} \mathrm{G}-966, \mathrm{~m}^{5} \mathrm{C}-1400, \mathrm{~m}^{4} \mathrm{Cm}-1402\right.$, and $\mathrm{m}^{3} \mathrm{U}-1498$ ) were determined by X-ray crystallography to support interaction between 16S RNA and the P-site codon and anticodon stem-loop (Korostelev et al. 2006). These observations reflect the net importance of modification to efficient ribosomal function, as has been stated (Decatur and Fournier 2002). The high level of modification in the upper portion of helix 44 in SSU RNA occurs at the interface with the LSU RNA, forming a cavity in which translation occurs. These modifications in h44 include six methyl groups each in Thermotoga and Thermus, opposite an analogous concentration of modifications on the $23 \mathrm{~S}$ side of the Thermus LSU (Mengel-Jorgensen et al. 2006). Mengel-Jorgensen et al. (2006) have concluded that the occurrence of modifications in the 23S RNA of Thermus principally at the RNA-RNA interface suggests that they play a role in modulating the RNA-RNA interface contact. Their conclusions are supported by the locations of modifications in 16S RNA from Thermotoga (present work), Thermus (Guymon et al. 2006), and a series of studies on E. coli (Brimacombe et al. 1993; Decatur and Fournier 2002), showing that the ribosomal subunit interface is intimately associated with post-transcriptional modifications.

\section{Modified nucleoside N-330-1404 in the decoding region of the RNA}

Unknown N-330 is remarkable in two ways: first, in terms of its structural properties as inferred thus far; second, its unexpected occurrence in another phylogenetic domain, at the same location in the SSU RNA of the archaeal mesophile $H$. volcanii. Interestingly, C-1404 has been reported as modified but with unknown structure in the RNase T1 SSU maps of five bacteria (Rozenski and McCloskey 2005), and two archaea, H. volcanii (Gupta et al. 1983) and S. solfataricus (Woese et al. 1984). C-1404 pairs with essentially universal G-1497 (Cannone et al. 2002) near the top of h44. N-330 is implied to be a derivative of cytidine by the corresponding gene sequence (Gupta et al. 1983). The molecular mass of $330 \mathrm{Da}$ is unique among all known modified nucleosides in RNA (see http://medlib.med.utah.edu/RNAmods) and suggests its structure to be more complex than any of the nine known modified cytidines in rRNA (Rozenski and McCloskey 2005). The accurate molecular mass of N-330 was measured as $330.117 \pm 0.002$ using a Micromass Q-Tof mass spectrometer. This value is consistent with an elemental composition of $\mathrm{C}_{12} \mathrm{H}_{18} \mathrm{~N}_{4} \mathrm{O}_{7}$ (calc. 330.1175), thus requiring a side chain having one $\mathrm{N}$ atom, with three $\mathrm{Ns}$ accounted for by the cytosine heterocycle. Unfortunately, the exact chemical structure of N-330-1404 cannot be further pursued due to laboratory closure and retirement of the corresponding author.

It is interesting to consider the possibility that the structures and distributions of post-transcriptionally modified nucleosides-the specific products of a sizable array of RNA modification enzymes-could, in some instances, be indicators of past horizontal transfer of DNA coding for modification enzymes. This notion is supported by the sharp lines of phylogenetic demarcation of some modified nucleoside families (Limbach et al. 1994; Motorin and Grosjean 1998). The possibility of lateral transfer was earlier raised (McCloskey et al. 2001) in light of the strong clustering of the (otherwise bacterial) anticodon nucleoside $\mathrm{mnm}^{5} \mathrm{~s}^{2} \mathrm{U}$ in tRNAs from the Methanococci, a lineage of methanogenic marine archaea. Interestingly, nucleoside $\mathrm{N}-330$ is the only rRNA nucleoside occurring in Thermotoga that is shared only by bacteria and archaea, all others (with the exception of $\mathrm{m}^{4} \mathrm{Cm}-1402$, which is uniquely bacterial) being found in all three phylogenetic domains. Nucleoside $\mathrm{N}-330$ might therefore be, in part, the product of RNA modification enzyme genes transferred horizontally between Haloferax and Thermotoga. This speculation is based on the report of extensive lateral transfer between Thermotoga and archaea (Aravind et al. 1998; Logsdon and Faguy 1999), such that almost one-quarter of the Thermotoga genome $(24 \%)$ was found to be archaeal in nature (Nelson et al. 1999). Work in the area of RNA modification enzymes (Leung et al. 1998), however, while extensive in some notable cases, such as the yeast tRNA modification enzymes (Johansson and Byström 2005) and the pseudouridine synthases (Ofengand and Fournier 1998), by its nature generally lags behind knowledge of modified nucleoside structures (now numbering about 106; see http:// medlib.med.utah.edu/RNAmods) and their phylogenetic distributions. Pursuit of this possibility that N-330 is a product of lateral gene transfer will require knowledge of the chemical structure of N-330, and also of the sequences of specific enzymes responsible for its formation.

\section{MATERIALS AND METHODS}

Thermotoga maritima MSB8 cells were grown at $80^{\circ} \mathrm{C}$ at The University of Georgia Bioexpression and Fermentation Facility, under the supervision of T.E. Davies, and RNA from this source was acquired in two ways. First, purified 16S rRNA was obtained as a gift from V. Ramakrishnan (Department of Biochemistry, University of Utah; present address MRC Laboratory of Molecular 
Biology, Cambridge, U.K.). Second, T. maritima 30S ribosomal subunits were obtained from the same source and 16S RNA was extracted from the $30 \mathrm{~S}$ ribosomes with TRI Reagent (Chomczynski and Sacchi 1987) following the manufacturer's protocol. 16S rRNAs (typically, $100 \mu \mathrm{g} ; 200 \mathrm{pmol}$ ) were digested totally to nucleosides with nuclease $\mathrm{P} 1$, phosphodiesterase I, and BAP (Crain 1990). Aliquots of RNA (5-100 pmol) were digested with 1000 units of RNase T1 (Ambion) in $10 \mathrm{mM}$ Tris+ $1 \mathrm{mM}$ EDTA, $\mathrm{pH} 7$ for $30 \mathrm{~min}$ at $37^{\circ} \mathrm{C}$ or $45 \mathrm{~min}$ at $55^{\circ} \mathrm{C}$. Alternatively, the RNA was digested with RNase U2 (Industrial Research Ltd.) in 20 $\mathrm{mM}$ diammonium citrate (DAC), $\mathrm{pH} 5,1 \mathrm{mM}$ EDTA, or in 20 mM DAC, pH 5, 1 mM EDTA, $8 \mathrm{M}$ urea, with 5-10 units RNase $\mathrm{U} 2$ for $15 \mathrm{~min}$ at $60^{\circ} \mathrm{C}$, then an additional 5-10 units of enzyme was added and digestion continued for $15 \mathrm{~min}$. Details of the mass spectrometry methods used in this study can be found in the Supplemental Data section.

\section{SUPPLEMENTAL DATA}

The following supplemental material can be found at http:// library.med.utah.edu/mccloskey: LC/ESI-MS analysis of nucleosides in Thermotoga 16S rRNA; partial chromatogram from LC/ESI-MS analysis of RNase U2 digest of Thermotoga 16S rRNA; assignments for monomer ions used in Table 1; data and discussion for placements of $\mathrm{m}^{7} \mathrm{G}, \mathrm{m}^{2} \mathrm{G}$ (two each), $\mathrm{m}^{5} \mathrm{C}, \mathrm{m}_{2}^{6} \mathrm{~A}$ (two each), and $\mathrm{Cm}$; additional comments on nucleoside $\mathrm{N}-330$; sequence mass spectrum of T1 oligonucleotide $M_{\mathrm{r}}$ 4591.7; mass spectrometry Materials and Methods.

\section{ACKNOWLEDGMENTS}

This work was supported by NIH Grant R01 GM29812 (J.A.M.). We are indebted to $\mathrm{V}$. Ramakrishnan for T. maritima ribosomes and rRNA, and to M. Tarry for preparative work in the V. Ramakrishnan laboratory. We thank H. F. Noller for a copy of his 70S ribosome-tRNA manuscript prior to publication, and F. Kirpekar for a preprint of his paper on T. thermophilus $23 \mathrm{~S}$ rRNA modifications.

Received October 27, 2006; accepted December 13, 2006.

\section{REFERENCES}

Agris, P.F. 2004. Decoding the genome: A modified view. Nucleic Acids Res. 32: 223-238.

Aravind, L., Tatusov, R.L., Wolf, Y.I., Walker, D.R., and Koonin, E.V. 1998. Evidence for massive gene exchange between archaeal and bacterial hyperthermophiles. Trends Genet. 14: 442-444.

Bachellerie, J.-P. and Cavaillé, J. 1998. Small nucleolar RNAs guide the ribose methylations of eukaryotic rRNAs. In Modification and editing of RNA (eds. H. Grosjean and R. Benne), pp. 255-272. ASM Press, Washington, DC.

Bakin, A., Kowalak, J.A., McCloskey, J.A., and Ofengand, J. 1994. A single pseudouridine residue in E. coli 16S RNA is located at position 516. Nucleic Acids Res. 22: 3681-3684.

Brimacombe, R., Mitchell, P., Osswald, M., Stade, K., and Bochkariov, D. 1993. Clustering of modified nucleotides at the functional center of the ribosome. FASEB J. 7: 161-167.

Brosius, J., Palmer, M.L., Kennedy, P.J., and Noller, H.F. 1978. Complete nucleotide sequence of a 16S ribosomal RNA gene from Escherichia coli. Proc. Natl. Acad. Sci. 75: 4801-4805.
Cannone, J.J., Subramanian, S., Schnare, M.N., Collett, J.R., D’Souza, L.M., Du, Y., Feng, B., Lin, N., Madabusi, L.V., Muller, K.M., et al. 2002. The comparative RNA web (CRW) site: An online database of comparative sequence and structure information for ribosomal, intron, and other RNAs. BMC Bioinformatics 3: 2 .

Chomczynski, P. and Sacchi, N. 1987. Single-step method of RNA isolation by acid guanidinium thiocyanate-phenol-chloroform extraction. Anal. Biochem. 162: 156-159.

Crain, P.F. 1990. Preparation and enzymatic hydrolysis of RNA and DNA for mass spectrometry. Methods Enzymol. 193: 782-790.

Cunningham, P.R., Weitzmann, C.J., Nègre, D., Sinning, J.G., Frick, V., Nurse, K., and Ofengand, J. 1990. In vitro analysis of the role of rRNA in protein synthesis: Site-specific mutation and methylation. In The ribosome: Structure, function, and evolution (eds. W.E. Hill et al.), pp. 243-252. ASM Press, Washington, DC.

Cunningham, P.R., Richard, R.B., Weitzmann, C.J., Nurse, K., and Ofengand, J. 1991. The absence of modified nucleotides affects both in vitro assembly and in vitro function of the 30S-ribosomal subunit of Escherichia coli. Biochimie 73: 789-796.

Davis, D.R. 1995. Stabilization of RNA stacking by pseudouridine. Nucleic Acids Res. 23: 5020-5026.

Davis, D.R. 1998. Biophysical and conformational properties of modified nucleosides in RNA (nuclear magnetic resonance studies). In Modification and editing of RNA (eds. H. Grosjean and R. Benne), pp. 85-102. ASM Press, Washington, DC.

Decatur, W.A. and Fournier, M.J. 2002. rRNA modifications and ribosome function. Trends Biochem. Sci. 27: 344-351.

Derrick, W.B. and Horowitz, J. 1993. Probing structural differences between native and in vitro transcribed Escherichia coli valine transfer RNA: Evidence for stable base modification-dependent conformers. Nucleic Acids Res. 21: 4948-4953.

Douthwaite, S., Fourmy, D., and Yoshizawa, S. 2005. Nucleotide methylations in rRNA that confer resistance to ribosome-targeting antibiotics. In Fine-tuning of RNA functions by modification and editing (ed. H. Grosjean), pp. 285-307. Springer-Verlag, Berlin.

Green, R. and Noller, H.F. 1996. In vitro complementation analysis localizes $23 \mathrm{~S}$ rRNA posttranscriptional modifications that are required for Escherichia coli 50 S ribosomal subunit assembly and function. RNA 2: 1011-1021.

Gupta, R., Lanter, J.M., and Woese, C.R. 1983. Sequence of the 16 S ribosomal RNA from Halobacterium volcanii, an archaebacterium. Science 221: 656-659.

Guymon, R., Pomerantz, S.C., Crain, P.F., and McCloskey, J.A. 2006. The influence of phylogeny on posttranscriptional modification of rRNA in thermophilic prokaryotes: The complete modification map of 16S rRNA of Thermus thermophilus. Biochemistry 45: 4888-4899.

Huber, R., Langworthy, T.A., König, H., Thomm, M., Woese, C.R., Sleytr, U.B., and Stetter, K.O. 1986. Thermotoga maritima sp. nov. represents a new genus of unique extremely thermophilic eubacteria growing up to $90^{\circ} \mathrm{C}$. Arch. Microbiol. 144: 324-333.

Johansson, M.J.O. and Byström, A.S. 2005. Transfer RNA modifications and modifying enzymes in Saccharomyces cerevisiae. In Fine-tuning of RNA functions by modification and editing (ed. H. Grosjean), pp. 87-120. Springer-Verlag, Berlin.

Kawai, G., Yamamoto, Y., Kamimura, T., Masegi, T., Sekine, M., Hata, T., Iimori, T., Watanabe, T., Miyazawa, T., and Yokoyama, S. 1992. Conformational rigidity of specific pyrimidine residues in tRNA arises from posttranscriptional modifications that enhance steric interaction between the base and the $2^{\prime}$ hydroxyl group. Biochemistry 31: 1040-1046.

Korostelev, A., Trakhanov, S., Laurberg, M., and Noller, H.F. 2006. Crystal structure of a 70s ribosome-tRNA complex reveals functional interactions and rearrangements. Cell 126: 1065-1077.

Kowalak, J.A., Dalluge, J.J., McCloskey, J.A., and Stetter, K.O. 1994. Role of posttranscriptional modification in stabilization of transfer RNA from hyperthermophiles. Biochemistry 33: 7869-7876.

Kowalak, J., Bruenger, E., Crain, P.F., and McCloskey, J.A. 2000. Identities and phylogenetic comparisons of post-transcriptional 
modifications in $16 \mathrm{~S}$ ribosomal RNA from Haloferax volcanii. J. Biol. Chem. 275: 24484-24489.

Leung, H.-C.E., Hagervall, T.G., Björk, G.R., and Winkler, M.E. 1998. Genetic locations and database accession numbers of RNAmodifying and -editing enzymes. In Modification and editing of RNA (eds. H. Grosjean and R. Benne), pp. 561-565. ASM Press, Washington, DC.

Limbach, P.A., Crain, P.F., and McCloskey, J.A. 1994. Summary: The modified nucleosides of RNA. Nucleic Acids Res. 22: 21832196.

Logsdon, J.M. and Faguy, D.M. 1999. Evolutionary genomics: Thermotoga heats up lateral gene transfer. Curr. Biol. 9: R747R751.

Maden, B.E.H. 1990. The numerous modified nucleosides in eukaryotic ribosomal RNA. Prog. Nucleic Acid Res. Mol. Biol. 39: 241-303.

Maden, B.E.H. 1998. Intracellular locations of RNA-modifying enzymes. In Modification and editing of RNA (eds. H. Grosjean and R. Benne), pp. 421-440. ASM Press, Washington, DC.

Mason, T.L. 1998. Functional aspects of the three modified nucleotides in yeast mitochondrial large-subunit rRNA. In Modification and editing of RNA (eds. H. Grosjean and R. Benne), pp. 273-280. ASM Press, Washington, DC.

McCloskey, J.A., Graham, D.E., Zhou, S., Crain, P.F., Ibba, M., Konisky, J., Söll, D., and Olsen, G.J. 2001. Post-transcriptional modification in archaeal tRNAs: Identities and phylogenetic relations of nucleotides from mesophilic and hyperthermophilic Methanococcales. Nucleic Acids Res. 29: 4699-4706.

McLuckey, S.A., Van Berkel, G.J., and Glish, G.L. 1992. Tandem mass spectrometry of small, multiply charged oligonucleotides. J. Am. Soc. Mass Spectrom. 3: 60-70.

Mengel-Jorgensen, J., Jensen, S.S., Rasmussen, A., Poehlsgaard, J., and Kirpekar, F. 2006. Modifications in Thermus thermophilus 23S ribosomal RNA are centered in regions of RNA-RNA contact. J. Biol. Chem. 281: 22108-22117.

Motorin, Y. and Grosjean, H. 1998. Appendix 1: Chemical structures and classification of posttranscriptionally modified nucleosides in RNA. In Modification and editing of RNA (eds. H. Grosjean and R. Benne), pp. 543-549. ASM Press, Washington, DC.

Nelson, K.E., Clayton, R.A., Gill, S.R., Gwinn, M.L., Dodson, R.J., Haft, D.H., Hickey, E.K., Peterson, J.D., Nelson, W.C., Ketchum, K.A., et al. 1999. Evidence for lateral gene transfer between Archaea and Bacteria from genome sequence of Thermotoga maritima. Nature 399: 323-329.

Noon, K.R., Bruenger, E., and McCloskey, J.A. 1998. Posttranscriptional modifications in $16 \mathrm{~S}$ and $23 \mathrm{~S}$ rRNAs of the archaeal hyperthermophile Sulfolobus solfataricus. J. Bacteriol. 180: 28832888.
Noon, K.R., Guymon, R., Crain, P.F., McCloskey, J.A., Thomm, M., Lim, M., and Cavicchioli, R. 2003. Influence of temperature on tRNA modification in Archaea: Methanococcoides burtonii $\left(\mathrm{T}_{\mathrm{opt}}\right.$ $23^{\circ} \mathrm{C}$ ) and Stetteria hydrogenophila $\left(\mathrm{T}_{\mathrm{opt}} 95^{\circ} \mathrm{C}\right) . J$. Bacteriol. 185: 5483-5490.

Ofengand, J. and Fournier, M.J. 1998. The pseudouridine residues of rRNA: Number, location, biosynthesis, and function. In Modification and editing of RNA (eds. H. Grosjean and R. Benne), pp. 229-253. ASM Press, Washington, DC.

Ofengand, J. and Rudd, K.E. 2000. Bacterial, archaeal, and organellar rRNA pseudouridines and methylated nucleosides and their enzymes. In The ribosome: Structure, function, antibiotics, and cellular interactions (eds. R.A. Garrett et al.), pp. 175-189. ASM Press, Washington, DC.

Phillips, D.R. and McCloskey, J.A. 1993. A comprehensive study of the low energy collision-induced dissociation of dinucleoside monophosphates. Int. J. Mass Spectrom. Ion Process. 128: 61-82.

Pomerantz, S.C. and McCloskey, J.A. 1990. Analysis of RNA hydrolyzates by LC/MS. Methods Enzymol. 193: 796-824.

Pomerantz, S.C. and McCloskey, J.A. 2005. Detection of the common RNA nucleoside pseudouridine in mixtures of oligonucleotides by mass spectrometry. Anal. Chem. 77: 4687-4697.

Rozenski, J. and McCloskey, J.A. 2005. The small subunit rRNA modification database. Nucleic Acids Res. 33: D135-D138.

Rydén-Aulin, M., Shaoping, Z., Kylsten, P., and Isaksson, L.A. 1993. Ribosome activity and modification of 16S RNA are influenced by deletion of ribosomal protein S20. Mol. Microbiol. 7: 983-992.

Sampson, J.R. and Uhlenbeck, O.C. 1988. Biochemical and physical characterization of an unmodified yeast phenylalanine transfer RNA transcribed in vitro. Proc. Natl. Acad. Sci. 85: 1033-1037.

Sirum-Connolly, K. and Mason, T.L. 1993. Functional requirement of a site-specific ribose methylation in ribosomal RNA. Science 262: 1886-1889.

Sirum-Connolly, K., Peltier, J.M., Crain, P.F., McCloskey, J.A., and Mason, T.L. 1995. Implications of a functional large ribosomal RNA with only three modified nucleotides. Biochimie 77: 3039.

Vaughan, M.H., Soeiro, R., Warner, J.R., and Darnell, J.E. 1967. Role of RNA methylation in rRNA maturation. Proc. Natl. Acad. Sci. 58: 1527-1534.

von Ahsen, U. and Noller, H.F. 1995. Identification of bases in 16S rRNA essential for tRNA binding at the $30 \mathrm{~S}$ ribosomal $\mathrm{P}$ site. Science 267: 234-237.

Woese, C.R., Gupta, R., Hahn, C.M., Zillig, W., and Tu, J. 1984. The phylogenetic relationships of three sulfur dependent archaebacteria. Syst. Appl. Microbiol. 5: 97-105. 

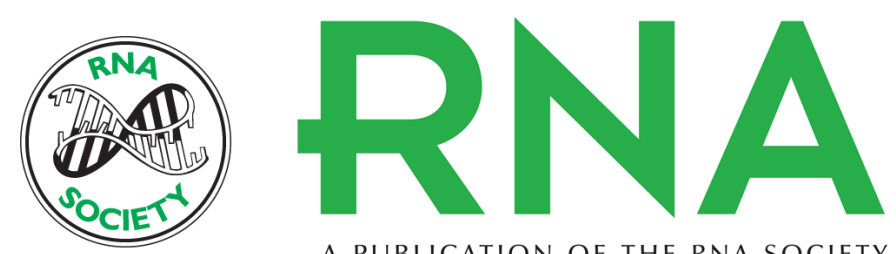

A PUBLICATION OF THE RNA SOCIETY

\section{Post-transcriptional modifications in the small subunit ribosomal RNA from Thermotoga maritima, including presence of a novel modified cytidine}

Rebecca Guymon, Steven C. Pomerantz, J. Nicholas Ison, et al.

RNA 2007 13: 396-403 originally published online January 25, 2007

Access the most recent version at doi:10.1261/rna.361607

References This article cites 39 articles, 11 of which can be accessed free at:

http://rnajournal.cshlp.org/content/13/3/396.full.html\#ref-list-1

License

Email Alerting Receive free email alerts when new articles cite this article - sign up in the box at the Service top right corner of the article or click here.

To subscribe to RNA go to:

http://rnajournal.cshlp.org/subscriptions 